\title{
Development of Textile Industrial Clusters in Pakistan
}

\author{
Muhammad Shahzad Iqbal (Corresponding author) \\ Department of Business Studies \\ The University of Faisalabad, Faisalabad, Pakistan \\ Tel: 92-300-866-0601Ｅ-mail: shahzad.iqbaal@gmail.com
}

Faiz. M. Shaikh

Assistant Professor, SZABAC-Dokri, Pakistan

E-mail: faizmuhammed_2000@yahoo.com

Dr. Babak Mahmood

Assistant Professor, Department of Business Studies

The University of Faisalabad, Pakistan

E-mail: babakmahmood@gmail.com

Kamran Shafiq

COMSATS-Abbott bad, Pakistan

E-mail: kamranhashmi@ciit.net.pk

\begin{abstract}
This research investigates the textile industry clusters in Pakistan. A cross sectional data were collected from 30 textile industries by using simple random technique and data were analysis by using E-Views software. Structural questionnaire was the basic tool for measures the performance of textile clusters in Pakistan. It was revealed that the industry is in urgent need of financial and technological investments. However, according to recent official figures, the Pakistan textile industry contributes more than $60 \%$ to the country's total exports, which amounts to around 5.2 billion US dollars. The manufacturing sector contributes to around half of the total exports and textile sector contributes around $46 \%$ of the manufacturing sector's contribution. The negative growth of $2.6 \%$ declining from \$ 16.4 billion last year to \$ 16.0 billion in July-April 2008-09. Ministry of Textile Industry should launch and endorse the development of cluster-based textiles vision. It further revealed that Government should emphasis on increase Efficiency and Productivity with the help of research and development department and identifies key areas for process.
\end{abstract}

Keywords: Textile, Clusters, Empirical analysis, Pakistan

\section{Introduction}

Textile Industry is one of the oldest industries in Pakistan and despites its inherent strengths; it is losing its competitiveness to other countries, especially in South East Asian Countries. The Industry is in urgent need of financial and technological investments. However, according to recent official figures, the Pakistan textile industry contributes more than $60 \%$ to the country's total exports, which amounts to around 5.2 billion US dollars. The industry contributes around $46 \%$ to the total output produced in the country. In Asia, Pakistan is the 8th largest exporter of textile products. The contribution of this industry to the total GDP is $8.5 \%$ (Economic Survey of Pakistan-2008-09). It provides employment to $38 \%$ of the work force in the country, which amounts to a figure of 15 million. However, the proportion of skilled labor is very less as compared to that of unskilled labor. All Pakistan Textile Mills Association is the chief organization that determines the rules and regulations in the Pakistan textile industry. Pakistan textile industry is currently facing several challenges. There is a need for the industry to improve the quality of its products. There is also the need for greater value addition in its products (Bari, 2003). The textile machinery used in Pakistan is imported mainly from countries like Japan, Switzerland, Germany, China and Belgium. Also, there is lack of efficient R\&D and training. Our main competitors in 
primary textile products with the advantage of large engineering sector in this region are China and India. The only country in this region without strong engineering base is Pakistan and our dependence upon outside Engineering Industry keeps our cost of production higher with low engineering skills. Looking into the future a strong competition from China and India for these market requirements can be used to involve them to start assembly plants under their guidance and cooperation. Some progress in the direction has led to the development of a Task Force in the Ministry of Industries and Textile Engineering is growingly lucrative for investors, local and foreigners.

This paper presents an analysis of the Textiles and Apparel Cluster in Pakistan. The report gives an overview of the socioeconomic performance of the country followed by an assessment of its business environment. It also explores the performance of the cluster with a special focus on its role in the national economy, its historic evolution, and analysis of the cluster Diamond. The penultimate section of this paper summarizes the strategic issues faced by the country and the cluster. The final section presents a set of recommendations to improve the performance of the cluster.

\section{Country Analysis}

\subsection{Background}

The population of Pakistan is approximately 181 million people and it is the sixth most-populous country. Geographically, it is situated in south Asia with its borders with India in the East and Afghanistan in the West. About $20 \%$ of the population lives below the international poverty line of US $\$ 1.25$ a day (Economic Survey of Pakistan-2008-09). The majority of southern Pakistan's population lives along the Indus River. By population size, Karachi is the biggest city of Pakistan. In the northern half, most of the population lives about an arc formed by the cities of Lahore, Faisalabad, Rawalpindi, Islamabad, Gujranwala, Sialkot, Gujrat, Jhelum, Sargodha and Shekhupura. Pakistan also faced a major set-back when East-Pakistan (now Bangladesh) seceded and became an independent nation. Pakistan geopolitical problems were further compounded by its strategic location and proximity to Afghanistan which made her a frontline state during the cold war against Russia. Now Pakistan is an important helper of the USA in the global war against terrorism, but unfortunately Pakistan also faces the swear condition of terrorism

\subsection{Economic Performance}

- The overall foreign investment during the first ten months (July-April) of the current fiscal year has declined by $42.7 \%$ and stood at $\$ 2.2$ billions against $\$ 3.9$ billion in the comparable period of last year.

- Foreign direct investment (private) showed some flexibility and stood at $\$ 3205.4$ million during the first ten months (July-April) of the current fiscal year as against \$3719.1 million in the same period last year thereby showing decline of $13.8 \%$.

- The total investment has declined from $22.5 \%$ of GDP in 2006-07 to $19.7 \%$ of GDP in 2008-09.

- Fixed investment has decreased to18.1 \% of GDP from $20.4 \%$ last year.

- Agriculture sector has depicted growth of $4.7 \%$ as compared to $1.1 \%$ witnessed last year and target of $3.5 \%$ for the year.

- Major crops accounting for $33.4 \%$ of agricultural value added registered a remarkable growth of $7.7 \%$ as against a negative growth of $6.4 \%$ last year and a target of $4.5 \%$.

- Pakistan's per capita real income has risen by $2.5 \%$ in 2008-09 as against 3.4 \% last year. Per capita income in dollar term rose from $\$ 1042$ last year to $\$ 1046$ in 2008-09, thereby showing marginal increase of $0.3 \%$.

- Manufacturing sector has contracted by $3.3 \%$ in 2008-09 as compared to expansion of $4.8 \%$ in last year and over-ambitious target of $6.1 \%$.

- Large-scale manufacturing depicted contraction of $7.7 \%$ as against expansion of $4.0 \%$ in the last year and $5.5 \%$ target for the year.

- Small and medium manufacturing sector maintained its healthy growth of last year at $7.5 \%$ (Economic Survey of Pakistan-2008-09).

\subsection{Trends in GDP Growth Rate}

The economy has lost significant growth drive due to massive contraction in the industrial sector. The current account deficit is likely to decelerate from as high as $8.5 \%$ of GDP to around $5.3 \%$ of GDP in 2008-09 a reduction of $3.2 \%$ age points in just one year. The improvement allowed for a build-up of the country's foreign exchange reserves beyond $\$ 11$ billion. Pakistan's economy still faces pressures from uncertain security 
environment, higher inflation in food prices. Pakistan's GDP is almost contract by $3 \%$ in average year 2009 . Real GDP grew by $2.0 \%$ in 2008-09 as against $4.1 \%$ last year and growth target of $4.5 \%$. The commodity producing sector witnessed marginal positive growth of $0.2 \%$ which is the lowest ever in the last eighteen years.

\subsection{Pakistan Export Situation}

The main export items of Pakistan are rice, furniture, cotton fiber, textiles, leather etc (Textile Vision 2005, 2000). Exports were targeted at \$ 19.0 billion or $6.9 \%$ lower than last year. Exports started to face global financial crisis since November 2008 and the contraction of world over demand has exacerbated export contraction. The manufacturing sector contributes to around half of the total exports and textile sector contributes around $46 \%$ of the manufacturing sector's contribution. The negative growth of $2.6 \%$ declining from $\$ 16.4$ billion last year to $\$ 16.0$ billion in July-April 2008-09.

In terms of export clusters, Pakistan's economy is mostly concentrated in textile \& apparel, leather goods, agricultural products, construction material, logistics, transportation, fruits, row cotton, fish, vegetables and sports good. Out of which Textile \& apparel are the biggest and the fastest growing clusters. The challenge for Pakistan is thus to develop other emerging clusters to expand its portfolio.

\section{Business Environment of Pakistan}

Pakistan's national business environment is characterized by abundance of semi-skilled and low wage labor, moderate natural resources, poor infrastructure, high rates of corruption, poor governance, moderate level of university-industry collaboration and low scientific research on the factor side. American Business Council of Pakistan (ABC), a formal association of American Multinationals operating in Pakistan conducts informal business survey annually to assess how their members view investment climate in Pakistan. The survey conducted in July - August, 2002, shows that Pakistan's economy is picking up and the investment environment is improving (sheikh, 2005).

\section{Key results of the survey:}

- $85 \%$ of respondents indicated improvement in Pakistan's overall economic prospects while $73 \%$ indicated improvement in Domestic Economy.

- $83 \%$ reported increase in their revenues in Rupees while $78 \%$ in US \$ terms.

- $79 \%$ observed that the policies were more consistent than before while $68 \%$ felt that the Government was positively impacting business.

- $75 \%$ indicated increase in their pre-tax profits.

- $63 \%$ indicated improvement in implementation of policies by the Government.

- $51 \%$ of the respondents reported that they were planning to expand investment in Pakistan.

\subsection{Trends in business environment and textile policy}

During the last five years, Pakistan has registered some significant improvement in the factor conditions. Islamabad (September 10 2009): The 'IFC-World Bank Doing Business-2010' report has projected no improvement in ease of doing business in Pakistan and the country continued to be ranked at 85th in world among 131 countries. According to the report available on World Bank website, Pakistan shows declining trends in ease of doing business the business ranking of Pakistan has been determined at 85 in Doing Business Report-2010. Whereas in Doing Business Report-2009 Pakistan was also ranked at 85th in the world, showing no improvement. Pakistan's ranking in starting a business has improved and the country has been ranked at 63rd in 2010 report whereas Pakistan was ranked 80th in 2009. In Pakistan some 10 procedures are required and it takes some 20 days and it costs $5.8 \%$ of income per capita.

Wage rate: Between 1994-2006, annual productivity growth average $1.2 \%$ while the corresponding wage figure was $3.63 \%$, and it affecting the ability of the country's competitiveness. And according to the World Bank report ease of employing workers in Pakistan has shown no improvement in 2008-09 and the country continued to rank at 146th in the world.

\section{Data Collection Methodology}

A cross sectional Data were collected from 30 textile industries by using simple random technique and data were analysis by using E-Views software. A structural questionnaire was developed as basic tool of measurement of textile industry in Pakistan. 


\section{Cluster Analysis}

\subsection{Importance of the Textile Cluster}

The Textiles and Apparels is the backbone of Pakistan's economy. In 2005, textile's contribution to overall GDP was $10 \%$ while its share in the exports was at a high of $60 \%$.

Moreover, it is the biggest source of employment in the country providing employment to more than 1.3 million people. About $38 \%$ of the manufacturing sector employment is in textile sector.

\subsection{Historic Perspective}

Pakistan's textile industry has long historic roots. In the Indus River Valley of Pakistan, cotton was being grown, spun and woven into cloth about 3,000 years BC (Cotton Counts 2007). The Production of textiles continued flourishing during different historic regimes such as Sultanate 10 period, Mughals dynasty and the British colonial times (Ali 1962). During the British colonial Regime, India was a primary supplier of raw cotton for textile mills based in Manchester and other parts of the United Kingdom. After Pakistan's independence in 1947, the textile industry continued to grow largely due to Government's investments in irrigation systems and attractive packages for industry start-ups. Over time, the share of textiles in Pakistan's overall economy as well as in the manufacturing sector remained significantly high.

\subsection{Trends in Textile Exports}

Pakistan is exporting around US $\$ 10$ billion of textile goods each year the exports of composed of both basic textile products such as yarn and value added exports including made-ups (www.aptma.org.pk).

\section{Textile Export:}

Overall exports are increasing with increase in the value-added exports. However, it also shows that value added exports as proportion of overall textiles Exports has largely remained same.

\subsection{Textile Value Chain}

A typical textiles value chain starts with cotton production which then passes through ginning where fiber is separated from the cotton seed. The next stage is spinning where the fiber is spun into yarn. At this stage, Manmade Fibers (MMF) such as polyester is also used as substitute for cotton fiber. The next stage of processing includes knitting and weaving depending on the type of fabric to be produced. The knitted or woven fabric then goes through dyeing and further processing such as bleaching. Once the fabric is processed, the last stage is stitching through which various made-ups are produced. Additional steps in the value chain include branding and retailing. These core activities of the value chain are facilitated by a network of supporting activities that include transport and logistics as well as export support.

\subsection{Textile Cluster Map}

The textile cluster contains a very diverse set of players and interconnections amongst the players. Some of the supporting include suppliers of machinery and tools; financial service providers, agriculture, transport and logistics. Whereas the textiles finished goods side, exporters, distributors and the leather clusters are important one.

\section{Textile Diamonds}

The textile cluster has generally shown a good performance in terms of overall growth. Nonetheless, the cluster has largely remained engaged in low-end of the value chain with heavy dependence on basic exports. The Diamond analysis identifies (in appendix) various strengths and weaknesses that have led to the current outlook of the textile cluster

\subsection{Condition of Demand}

Pakistan's textiles cluster heavily depends on global market. Currently, the global demand for textiles account for US $\$ 300$ billion which is likely to increase to US $\$ 800$ billion within the next 10 years. In addition to increasing global demand, Pakistan is also enjoys a huge domestic demand owing to its huge population size i.e. 160 million. Currently Pakistan caters to about $3 \%$ of the global demand as it produces about US $\$ 10$ bn worth of textile products. China has the highest market share in global textile market, followed by India and Pakistan in the region (see table in appendix)

In terms of export destination, Pakistan is heavily dependent on European countries, USA and the Middle East. In addition to clothes Pakistan also exports cotton yarn and basic textiles to East Asian countries. 


\subsection{Related Industries}

The growth of related industries in the textile cluster has largely taken place in the informal sector in a very haphazard manner. There are examples of organic clustering but a conscious effort on the part of industry players or government to promote a cluster based approach have always lacked. Generally, the capacity of related and supporting industries is often weak. Though, the linkage between various actors is also a cause of concern but there are some examples where the norms of reciprocity and interaction are very high. Faisalabad, one of the largest textile producing cities in Pakistan gives a good example of organic clustering and interconnection amongst the members. Table in appendix gives the list of variety of players that are involved in the textiles sector.

\subsection{Factor Conditions}

As textiles cluster involves diverse set of activities requiring different of inputs, a detailed analysis of factors conditions across the value chain is required. Figure 1 summarizes the factor conditions faced by the cluster. Across the value chain, low cost of labor emerges as the major strength. The estimated cost of labor was 43 cents for Pakistan followed by 47 cents in India, 57 cents in China, 52 cents in Indonesia and 60 cents in Egypt while Bangladesh and Vietnam outweighed this advantage with even lower costs 27 and 29 cents respectively (BR 2007). However, gaps in skill set of labor and poor technology - two major constraints faced by the cluster largely offset advantage of cheap labor.

\section{Strengths}

Pakistan is the fourth largest producer of cotton ( $9 \%$ world share) and is endowed with fertile lands and extensive irrigation network (USDA 2007; UNU 2007). However, the cotton sub-sector faces serious productivity and quality gaps. The cotton yields for Pakistan were $586 \mathrm{kgs} / \mathrm{hectare}$ compared to $1129 \mathrm{kgs} / \mathrm{hectare}$ in China in 1999-2000. Moreover, most of the commercial varieties of cotton were of small to medium length $(22 \mathrm{~mm}-28 \mathrm{~mm})$ with coarse texture (SMEDA 2000). One of the major contributing factor to this low productivity and poor quality is non-adoption of modern planting techniques such as furrow planting which is $6-7 \%$. At the ginning, spinning and weaving stages, dependence on outdated and less efficient technology is seriously hampering the productivity rates. For instance, the processing rate at the ginning stage is 8.3 bales per hour compared to 20 in the case of USA. Similarly, the spinning sector is largely dependent on less efficient technology e.g. spindles (9.2million units) compared to a meager 147,852 units of routers (Ibid). Similarly, weaving sector is dominated by conventional looms. The ratio of conventional power looms to shuttle-less looms is estimated to be 1 to 92 (2006).

Gaps in skill set of labor force only add to the problem of low productivity. Informal apprenticeship mechanism such as Shagirdi is the dominant form of skill transfer which eventually leads to inconsistencies in product quality. Ultimately, these inhibiting factor conditions, such as low quality of raw material, poor technology and insufficient skills, lead to low value addition and high defect rates. For example, $40 \%$ of exported fabric was grey in 2000 - an indicator of low value addition. Similarly, the defect rate at the processing/printing stage was $10 \%$ (SMEDA 2000). It is pertinent to mention here that the overall factor conditions of the country particularly those related to road infrastructure and energy also play significant role shaping the productivity of textile sector. For instance, cost of freight from China to USA was 50\% cheaper than that from Pakistan (GoP, 2007).

\subsection{Context for Firm Strategy and Rivalry}

Pakistan's Textiles and Apparels industry is highly fragmented comprising many small-scale players with majority of them working in the unorganized sector (see Table). This fragmentation and emergence of small-scale operators is partly due to government policies of the past which declared unit size 40 looms and below as cottage industry and hence provided exemption from tax and stringent labor policies (2006).

Another important feature of the textile industry in Pakistan is that it is largely dominated by family owned businesses. For instance, in Faisalabad, largest textiles producing city in Pakistan, three families dominated the business and trade groups. This, on the one hand, promoted trust and effective contract enforcement thus reducing transaction cost, it also led to regulatory 'capture' thus diverting government incentives to benefit a few and stifled the competition (2006). Some policies of the government with regards to taxes as well as incentives have been listed in the Figur-2.

World Bank notes that textile sector suffered from low diversification due to government restrictive policies on import of polyester (25\% tariff rate) coupled with poor administration of import duties and duty rebates schemes (World Bank, 2002). Lack of access of finances constitutes another important constraint for large number of small businesses in the cluster as the banking system is more aligned to serving large scale firms (2006). 


\section{Challenges Faced by Textile Cluster}

- Unavailability of standard raw material.

- Lack of skilled workers.

- Poor coordination between cluster players.

- Financial problems.

- Gaps in quality of local suppliers.

- Increase global competition.

- Low foreign direct investment.

- Not setting specific strategies.

- High tax rates.

- Poor state of technology and production process.

- Lack of specialized workers.

- Excessive dependence on textiles and apparel cluster and limited diversification of exports.

- Poor governance and its implication for overall business environment and foreign investment.

- Rising Cotton Prices.

- China and India being considered as countries for high value added garments.

- Limited use of modern technology.

- Confusion in political / religious scenario.

- Low levels of managerial capabilities.

- Poor physical infrastructure.

- Lack of a well coordinated approach at the cluster level

\section{Conclusions}

Pakistan is the fourth largest producer of cotton ( $9 \%$ world share) and is endowed with fertile lands and extensive irrigation network (USDA 2007; UNU 2007). However, the cotton sub-sector faces serious productivity and quality gaps. The cotton yields for Pakistan were $586 \mathrm{kgs} /$ hectare compared to $1129 \mathrm{kgs} / \mathrm{hectare}$ in China in 1999-2000. Moreover, it is the biggest source of employment in the country providing employment to more than 1.3 million people. About $38 \%$ of the manufacturing sector employment is in textile sector. The manufacturing sector contributes to around half of the total exports and textile sector contributes around $46 \%$ of the manufacturing sector's contribution. The negative growth of $2.6 \%$ declining from $\$ 16.4$ billion last year to $\$ 16.0$ billion in July-April 2008-09

\section{Recommendation}

After all above data we recommend that we need to be done.

- Ministry of Textile Industry should launch and endorse the development a cluster-based textiles vision.

- Increase Efficiency and Productivity with the help of research and development department and identify key areas for process.

- Improve supply chain management.

- Government should coordinate with private sector.

- Initiate educational and awareness programs for firms in the textile industry on the business value of formal and modern training.

- Building Logistic Capabilities.

- Developing long term relationships with Clients.

- Collaborating with buyers on forecasting and inventory management.

- Investing in IT infrastructure and compliance.

- Think Value Not Price.

- Be on the Cutting Edge of Performance. 
- Reduce Cycle Time, Improve Flexibility.

- Redefine Strategic Partnership.

- Encourage private sector, increase public expenditure, and work with international institutions such as the World Bank and Asian Development Bank to improve the infrastructure particularly energy by exploiting the huge hydroelectricity potential available in the country.

- Diversify the export portfolio by facilitating the development of multiple clusters particularly in the areas of logistics and communication, medical devices, horticulture, and tourism.

- Development of skills in labor and offer trainings time to time.

- Conduct global market research in textile apparels.

\section{References}

[Online] Available: htps://www.cia.gov/cia/publications/factbook/geos. (14/10/2009).

[Online] Available: http://www.brecorder.com. (10/11/2009).

[Online] Available: http://www.cybercity.online.net/yp/OPs/html/mnc_s_views_of_business_enviro.html. (19/12/2009).

[Online] Available: http://www.khaleejtimes.com/pakistan/Textileindustry.asp. (20/12/2009).

[Online] Available: http://www.links of emo project|Population Association of Pakistan-Statistics.html. $(10 / 12 / 2009)$.

[Online] Available: http://www.pap.org.pk/statistics/Economy.html. (10/12/2009).

[Online] Available: http://www.ptj.com.pk/Web\%202004/03-2004/trend.html. (30/11/2009).

A Survey of owner managed business Department of Employee, September 1990.

All Pakistan Textile Mills Association (APTMA). [Online] Available: www.aptma.org.pk. (14/10/2007).

Bari, K. Malik (2003). The Competitive Advantage of Pakistan - Empirical Analysis of the Textile/Apparel Industry, PhD Thesis, University of Strathclyde, Glasgow, U.K.

Cotton Counts 2007. [Online] Available: (20/11/2009).

Economist Intelligence Unit's. [Online] Available: www.eiu.com. (25/11/2009).

Government of Pakistan, (various years), Economic Survey of Pakistan, Ministry of Finance, Islamabad.

Government of Pakistan, (various years), Pakistan Statistical Year Book, Federal Bureau of Statistics (FBS), Statistics Division, Islamabad.

Government of Pakistan. (2000). Textile Vision 2005. Islamabad, Pakistan.

Government of Pakistan. (2002). Ministry of Commerce, Text of the Trade Policy of Pakistan, Islamabad, Pakistan.

Khan, S. R. (1999). Fifty Years of Pakistan Economy: Traditional Topic and Contemporary Concerns. Oxford University Press, Karachi, Pakistan.

Sheikh, H. R. (2005). Growth and BMR Requirements of the Textile Industry - Problems and Prospects, Textile Institute of Pakistan.

Small and Medium Enterprise Development Agency (SMEDA), 2000. [Online] Available: www.smeda.org. (28/12/2009).

Trade Development Authority of Pakistan. [Online] Available: www.epb.gov.pk. (25/12/2009).

United States Department of Agriculture (USDA). (2007). [Online] Available: www.usda.gov. (30/12/2009).

World Development Indicators various issues

[Online] Available: www.pakistan.gov.pk/ministries/index.jsp?MinID. (10/10/2009).

[Online] Available: www.epb.gov.pk. (20/11/2009).

[Online] Available: www.worldbank.org. (20/12/2009). 


\section{Appendix (Tables and Figures)}

Table 2.1.

\begin{tabular}{|l|l|l|l|l|}
\hline Year & GDP-real growth rate & Rank & Recent Change & Date of Information \\
\hline 2003 & $4.50 \%$ & 48 & & FY01/02 est. \\
\hline 2004 & $5.50 \%$ & 45 & $22.22 \%$ & 2003 est. \\
\hline 2005 & $6.10 \%$ & 47 & $10.91 \%$ & 2004 est. \\
\hline 2006 & $6.60 \%$ & 48 & $8.20 \%$ & 2005 est. \\
\hline 2007 & $6.60 \%$ & 59 & $0.00 \%$ & 2006 est. \\
\hline 2008 & $5.30 \%$ & 104 & $-19.70 \%$ & 2007 est. \\
\hline
\end{tabular}

Source: World Development Indicators, 2008-09

Table 2.2 Pakistan share of major commodities in worlds contribution

\begin{tabular}{|c|c|c|c|c|c|c|c|c|}
\hline & 1977 & 1982 & 1987 & 1989 & 1991 & 1992 & 1993 & 1994 \\
\hline \multicolumn{9}{|l|}{ Total Export } \\
\hline World Total & 1041000 & 1882355 & 2527885 & 3080000 & 3506000 & 3642000 & 3257589 & 3617591 \\
\hline Pakistan & 1283 & 2348 & 4105 & 4698 & 6464 & 7264 & 6842 & 7328 \\
\hline Share & 0.12 & 0.12 & 0.16 & 0.15 & 0.18 & 0.20 & 0.21 & 0.20 \\
\hline \multicolumn{9}{|c|}{ Textile and Clothing } \\
\hline World Total & 69071 & 75217 & 166200 & 193900 & 196834 & 222708 & 217926 & 238433 \\
\hline Pakistan & 1521 & 1071 & 2447 & 2734 & 4423 & 5041 & 5091 & 5593 \\
\hline Share & 2.20 & 1.42 & 1.47 & 1.41 & 2.25 & 2.26 & 2.34 & 2.35 \\
\hline \multicolumn{9}{|c|}{ Leather and Leather Goods } \\
\hline World Total & 2339 & 4115 & 7949 & 8706 & 10660 & 11751 & 12697 & 14645 \\
\hline Pakistan & 64 & 104 & 270 & 265 & 271 & 254 & 240 & 269 \\
\hline Share & 2.74 & 2.53 & 3.40 & 3.04 & 2.54 & 2.16 & 1.89 & 1.84 \\
\hline \multicolumn{9}{|c|}{ Fish and Fish Products } \\
\hline World Total & 23862 & 12225 & 22126 & 24588 & 31982 & 33038 & 33384 & 36531 \\
\hline Pakistan & 36 & 79 & 121 & 92 & 110 & 137 & 202 & 143 \\
\hline Share & 0.15 & 0.65 & 0.55 & 0.37 & 0.34 & 0.41 & 0.61 & 0.39 \\
\hline \multicolumn{9}{|c|}{ Carpets, Carpeting and Rugs } \\
\hline World Total & 531 & 857 & 1089 & 1199 & 1123 & 1346 & 1440 & 1213 \\
\hline Pakistan & 103 & 136 & 225 & 224 & 217 & 204 & 158 & 187 \\
\hline Share & 19.40 & 15.90 & 20.66 & 18.70 & 19.32 & 15.16 & 10.97 & 15.42 \\
\hline
\end{tabular}

Source: General of economic corporation among Islamic countries 
Table 2.3. Export, Import and Balance of Trade

\begin{tabular}{|l|c|c|c|c|c|c|}
\hline \multirow{2}{*}{ Series } & \multirow{2}{*}{ * November, 2006 } & \multicolumn{2}{c|}{ * October, 2006 } & \multicolumn{2}{c|}{$\begin{array}{c}\text { \% Change in } \\
\text { November, 2006 over } \\
\text { October, 2006 }\end{array}$} \\
\cline { 2 - 7 } & Rs. & $\$$ & Rs. & $\$$ & Rs. & $\$$ \\
\hline Exports & 83,805 & $1,380,001$ & 77,688 & $1,282,058$ & 7.87 & 7.64 \\
\hline Imports & 168,433 & $2,773,554$ & 129,170 & $2,131,662$ & 30.40 & 30.11 \\
\hline Balance of Trade & $-84,628$ & $-1,393,553$ & $-51,482$ & $-849,604$ & 64.38 & 64.02 \\
\hline
\end{tabular}

\begin{tabular}{|l|c|c|c|c|c|c|}
\hline \multirow{2}{*}{ Series } & \multirow{2}{*}{ * November, 2006 } & \multicolumn{2}{c|}{ November, 2005 } & \multicolumn{2}{c|}{$\begin{array}{c}\text { \% Change in } \\
\text { November, 2006 over } \\
\text { November, 2005 }\end{array}$} \\
\cline { 2 - 7 } & Rs. & $\$$ & Rs. & $\$$ & Rs. & $\$$ \\
\hline Exports & 83,805 & $1,380,001$ & 66,546 & $1,113,472$ & 25.94 & 23.94 \\
\hline Imports & 168,433 & $2,773,554$ & 137,400 & $2,299,021$ & 22.59 & 20.64 \\
\hline Balance of Trade & $-84,628$ & $-1,393,553$ & $-70,854$ & $-1,185,549$ & 19.44 & 17.54 \\
\hline
\end{tabular}

\begin{tabular}{|l|c|c|c|c|c|c|}
\hline \multirow{2}{*}{ Series } & \multicolumn{2}{|c|}{$\begin{array}{c}\text { * July - November } \\
2006\end{array}$} & \multicolumn{2}{c|}{$\begin{array}{c}\text { July - November } \\
2005\end{array}$} & \multicolumn{2}{c|}{$\begin{array}{c}\text { \% Change in } \\
\text { - November, 2006 over } \\
\text { July- November, 2005 }\end{array}$} \\
\cline { 2 - 7 } & Rs. & $\$$ & Rs. & $\$$ & Rs. & $\$$ \\
\hline Exports & 418,937 & $6,927,683$ & 393,548 & $6,591,866$ & 6.45 & 5.09 \\
\hline Imports & 745,989 & $12,333,301$ & 667,277 & $11,176,213$ & 11.80 & 10.35 \\
\hline Balance of Trade & $-327,052$ & $-5,405,618$ & $-273,729$ & $-4,584,347$ & 19.48 & 17.91 \\
\hline
\end{tabular}

Source: Govt. of Pakistan statistic division federal bureau of statistic

Provisional figures are based on figure provided by the member (FB\&S) CBR, Islamabad.

Note: Rupee value is converted into US\$ on monthly average exchange rate for November 2006 (1\$+Rs.60.728219)

Table 4.1. Sector wise Share of Textiles

\begin{tabular}{|l|l|l|}
\hline Sno & Sector & Ranking \\
\hline 1 & Share in merchandize exports & $63 \%$ \\
\hline 2 & Share in manufacturing sector & $46 \%$ \\
\hline 3 & Share in manufacturing sector employment & $38 \%$ \\
\hline 4 & Share in GDP & $9 \%$ \\
\hline 5 & Ranking in World textile trade & $10^{\text {th }}$ \\
\hline 6 & Ranking in World Clothing Trade & $15^{\text {th }}$ \\
\hline
\end{tabular}


Table 4.2. Share of Textiles in Employment

\begin{tabular}{|l|l|}
\hline Sub-sector & \# of people \\
\hline Ginning & 10,000 \\
\hline Spinning & 201,152 \\
\hline Weaving & 294,213 \\
\hline Knitting & 47,221 \\
\hline Processing and Finishing & 61,206 \\
\hline Stiching & 734,805 \\
\hline Total & $1,348,597$ \\
\hline
\end{tabular}

Table 4.3. Export of textile

\begin{tabular}{|c|c|c|c|}
\hline Year & Textile & Apparel & Total \\
\hline 1995 & 4.26 & 1.61 & 5.87 \\
\hline 1996 & 4.92 & 1.87 & 6.79 \\
\hline 1997 & 4.61 & 1.81 & 6.42 \\
\hline 1998 & 4.3 & 1.81 & 6.14 \\
\hline 1999 & 4.26 & 1.86 & 6.11 \\
\hline 2000 & 4.53 & 2.14 & 6.67 \\
\hline 2001 & 4.53 & 2.14 & 6.67 \\
\hline 2002 & 4.79 & 2.23 & 7.02 \\
\hline 2003 & 5.81 & 2.71 & 8.52 \\
\hline 2004 & 6.13 & 3.03 & 9.16 \\
\hline 2005 & 7.09 & 3.6 & 10.69 \\
\hline 2006 & 7.47 & 3.91 & 11.38 \\
\hline
\end{tabular}

Source: All Pakistan Textile Mills Association (AMPTA)

Table 4.4. Country wise analysis

\begin{tabular}{|l|l|l|l|}
\hline Countries & Textile & Apparel & Total \\
\hline Pakistan & 7.47 & 3.91 & 11.38 \\
\hline China & 48.68 & 95.39 & 144.07 \\
\hline India & 9.33 & 10.19 & 19.52 \\
\hline Bangladesh & 0.23 & 7.18 & 7.41 \\
\hline Veitnam & 0.63 & 4.9 & 5.53 \\
\hline Indonesia & 3.6 & 5.7 & 9.3 \\
\hline
\end{tabular}

Source: All Pakistan Textile Mills Association (AMPTA) 
Table 5.1. Global market share 2005-06

\begin{tabular}{|c|c|c|c|c|}
\hline \multirow[b]{2}{*}{ Countries } & \multicolumn{2}{|c|}{ Production } & \multicolumn{2}{|c|}{ Consumption } \\
\hline & 000 tons & $\%$ of World & 000 tons & $\%$ of World \\
\hline Pakistan & 2,058 & $9 \%$ & 2,584 & $11 \%$ \\
\hline China & 5,700 & $24 \%$ & 10,000 & $41 \%$ \\
\hline India & 4,148 & $18 \%$ & 3,655 & $15 \%$ \\
\hline Total of the above three & 11,906 & $50 \%$ & 16,239 & $67 \%$ \\
\hline Others & 11,740 & $50 \%$ & 8,095 & $33 \%$ \\
\hline World Total & 23,646 & & 24,334 & \\
\hline
\end{tabular}

Table 5.2. Participants in the Textile Cluster

\begin{tabular}{|l|l|l|l|l|l|}
\hline S No & $\begin{array}{l}\text { Textile Sub-Sector } \\
\text { Activities }\end{array}$ & $\begin{array}{l}\text { No. of } \\
\text { Firms }\end{array}$ & $\begin{array}{l}\text { S. } \\
\text { No }\end{array}$ & $\begin{array}{l}\text { Textile Sub-Sector } \\
\text { Activities }\end{array}$ & $\begin{array}{l}\text { No. of } \\
\text { Firms }\end{array}$ \\
\hline 1 & Cotton ginning and pressing & 26 & 11 & Textile composite & 4 \\
\hline 2 & Cotton waste processing & 53 & 12 & Textle weaving (independent units) & 32 \\
\hline 3 & Doubling of yarn & 22 & 13 & Textle weaving (power looms) & 1500 \\
\hline 4 & Embroidery & 21 & 14 & Textle exporters & 700 \\
\hline 5 & Hosiery products & 301 & 15 & Yarn merchants & 800 \\
\hline 6 & Ready-made garments & 40 & 16 & Fabric Whole Sellers & 300 \\
\hline 7 & $\begin{array}{l}\text { Sizing of yarn } \\
\text { (printing/dyeing/finishing) }\end{array}$ & 119 & 17 & $\begin{array}{l}\text { Textle Chemicals and Dye } \\
\text { Manufacturers }\end{array}$ & 9 \\
\hline 8 & $\begin{array}{l}\text { Textile machinery, parts and } \\
\text { service }\end{array}$ & 197 & 18 & $\begin{array}{l}\text { Whole Sellers of Textle Chemicals \& } \\
\text { Dyes }\end{array}$ & 200 \\
\hline 9 & $\begin{array}{l}\text { Textile processing } \\
\text { Textle spinning }\end{array}$ & 42 & 20 & $\begin{array}{l}\text { Other Textle Firms } \\
\text { (carpets, Towels etc) }\end{array}$ & 6 \\
\hline
\end{tabular}

Source: U1 Islam F. (2006) 
Table 5.3. Industry Structure and Capacity

\begin{tabular}{|c|c|c|c|}
\hline Sub-Sector & No of Units & Installed Capacity & Production \\
\hline Ginning & 1,221 & 5,488 Saws & 10,314 M Bales \\
\hline Spinning & 445 & $\begin{array}{l}\text { a. } 9,217 \text { Spindles } \\
\text { b. } 147,852 \text { Routers }\end{array}$ & $\begin{array}{l}1,758 \mathrm{M} . \mathrm{Kgs} . \\
\text { Yarn }\end{array}$ \\
\hline $\begin{array}{l}\text { Weaving } \\
\text { a. Composite Units } \\
\text { b. Independent Mills } \\
\text { c. Power Loom Sector }\end{array}$ & $\begin{array}{l}\text { a. } 50 \\
\text { b. } 140 \\
\text { c. } 18,000\end{array}$ & $\begin{array}{l}\text { 20,000-25,000 Shuttle-less looms } \\
225,000 \text { Conventional looms }\end{array}$ & $\begin{array}{l}\text { 5,6000 M. Sq } \\
\text { MT (Approx) }\end{array}$ \\
\hline $\begin{array}{l}\text { Finishing } \\
\text { a. Organized } \\
\text { b. Small Scale Sector }\end{array}$ & $\begin{array}{l}\text { a. } 106 \\
\text { b. } 625\end{array}$ & - & $\begin{array}{l}2,700 \text { M. Sq. } \\
\text { MT }\end{array}$ \\
\hline Garment Units & 5,000 & 450,000 Sewing Machines & $650 \mathrm{M} \mathrm{Pcs}$ \\
\hline Terry Towels & 400 & 7,600 looms & 55 M. Kgs. \\
\hline Canvas & 100 & 2,000 looms & 35 M. Kgs \\
\hline Knitwear & 700 & 21,000 Knitting Machines & 5.50 M. Pcs \\
\hline
\end{tabular}

Source: U1 Islam 2006

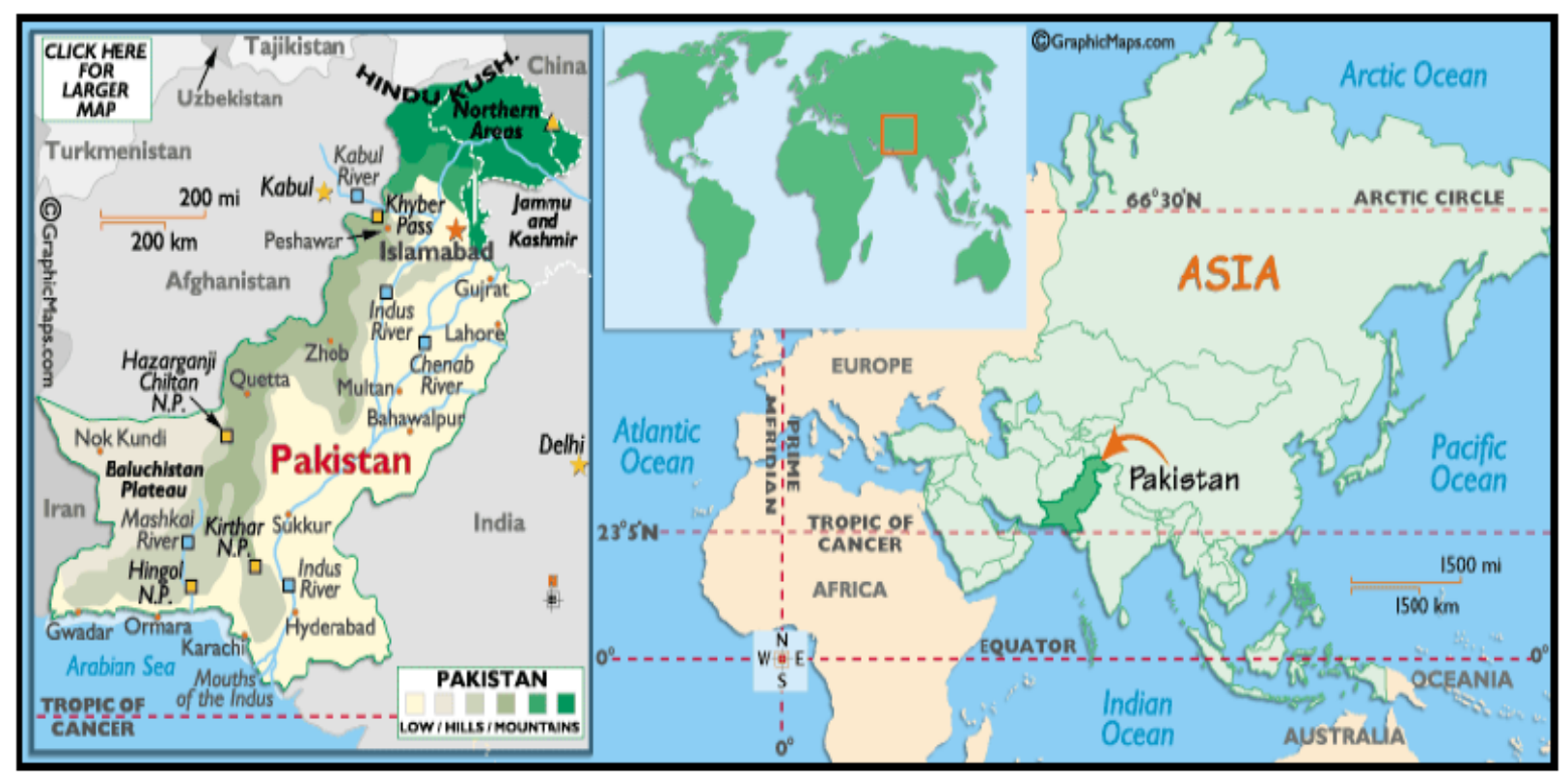

Source: World Atlas 2007

Figure 2.1. 


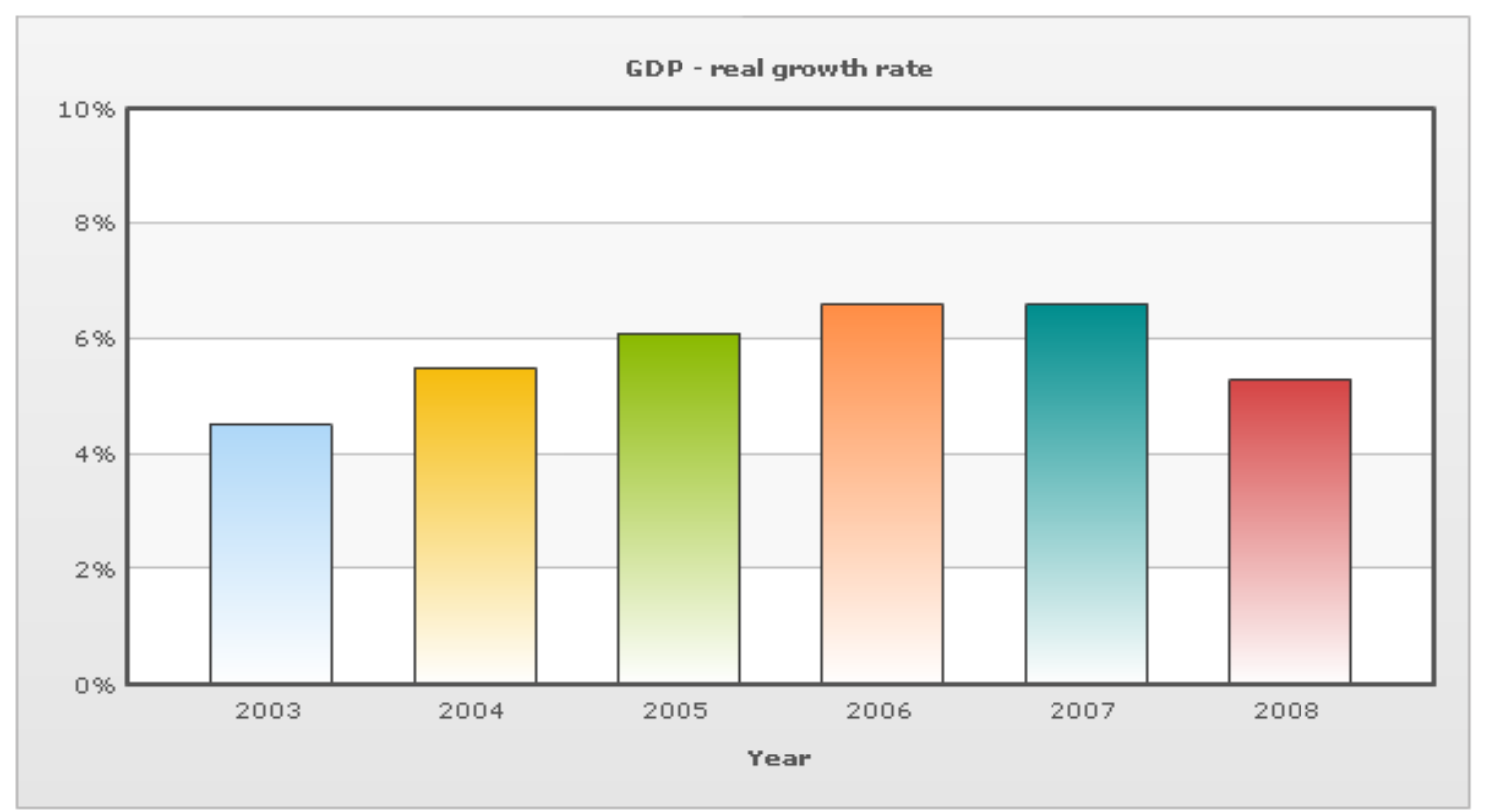

Source: World Development Indicators, 2008-09

Figure 2.2.

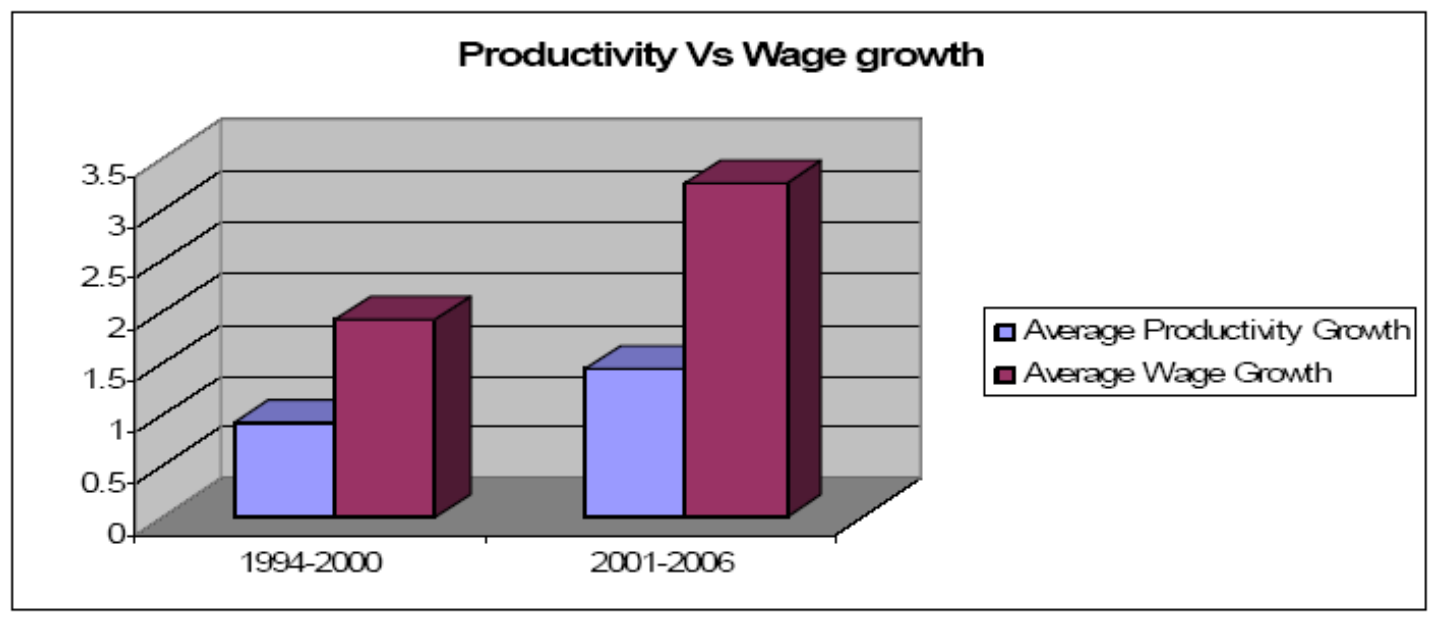

Source: Economist Intelligence Unit's

Figure 3.1. 


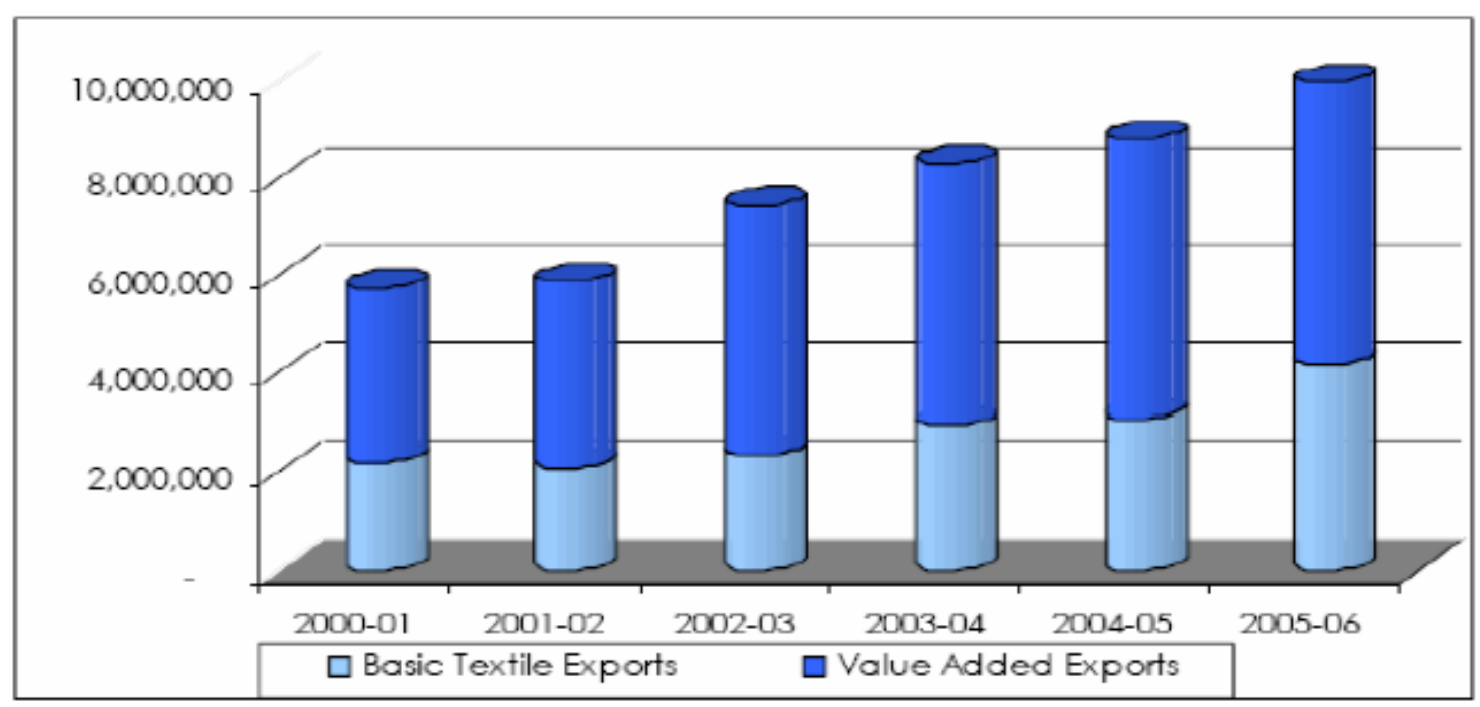

Source: All Pakistan Textile Mills Association (APTMA)

Figure 4.1. Trends in Textile Exports

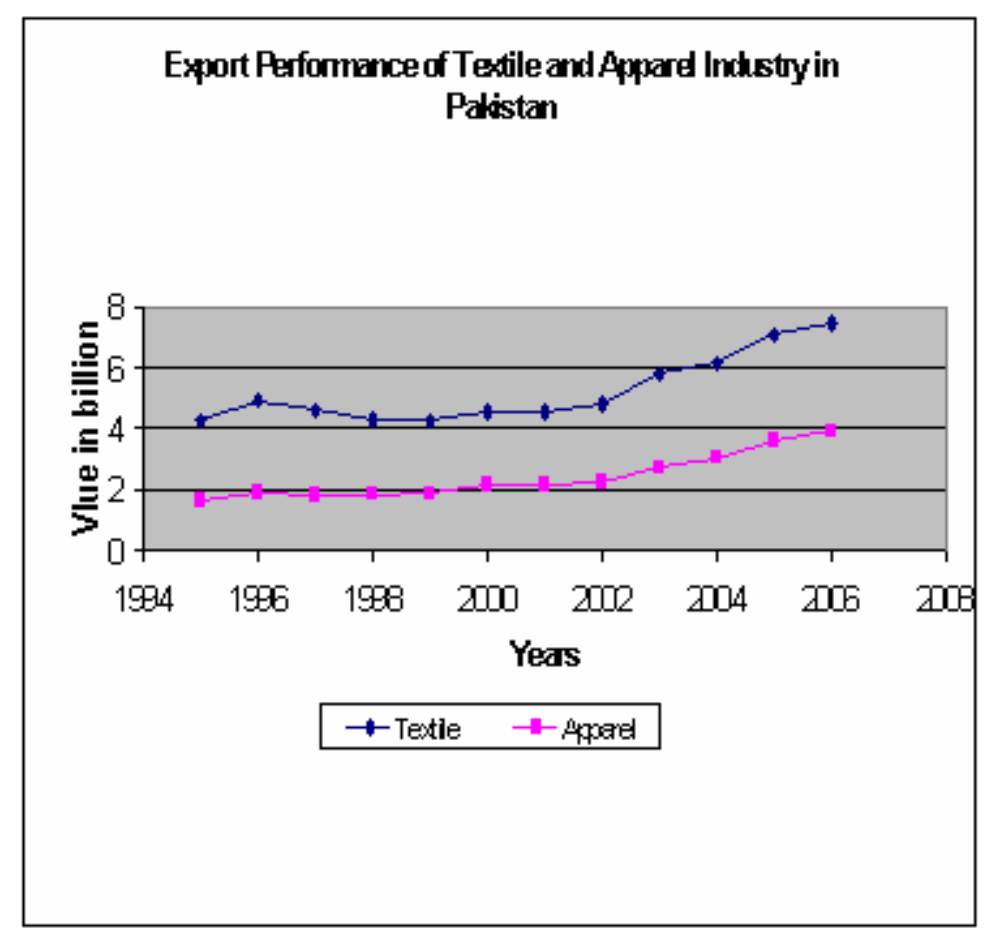

Source: All Pakistan Textile Mills Association (AMPTA)

Figure 4.2. Export of textile 


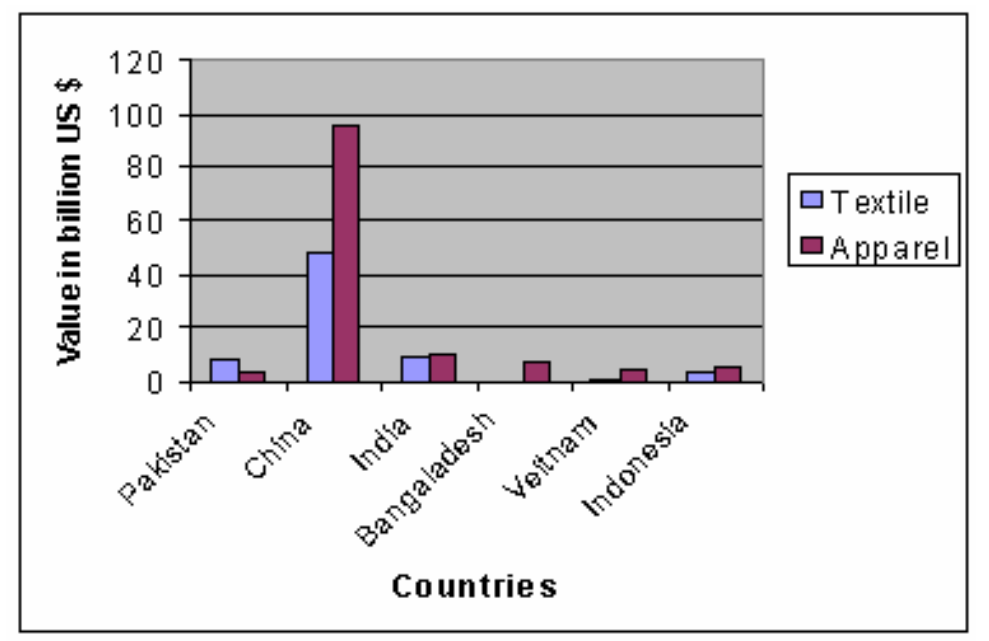

Source: All Pakistan Textile Mills Association (AMPTA)

Source: AMPTA

Figure 4.3. Pakistan Vs Major competitor

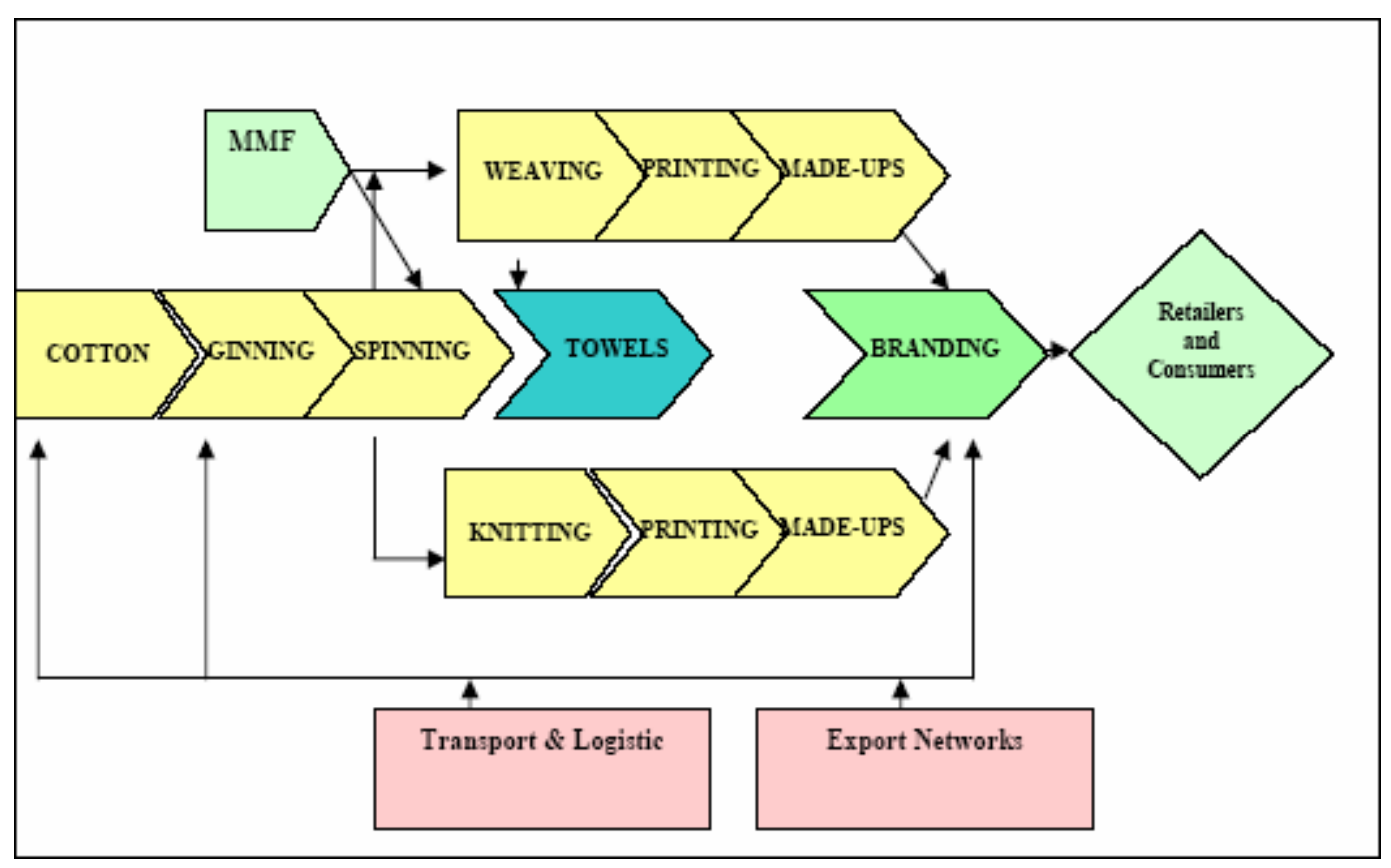

Figure 4.4. Textile Value Chain 


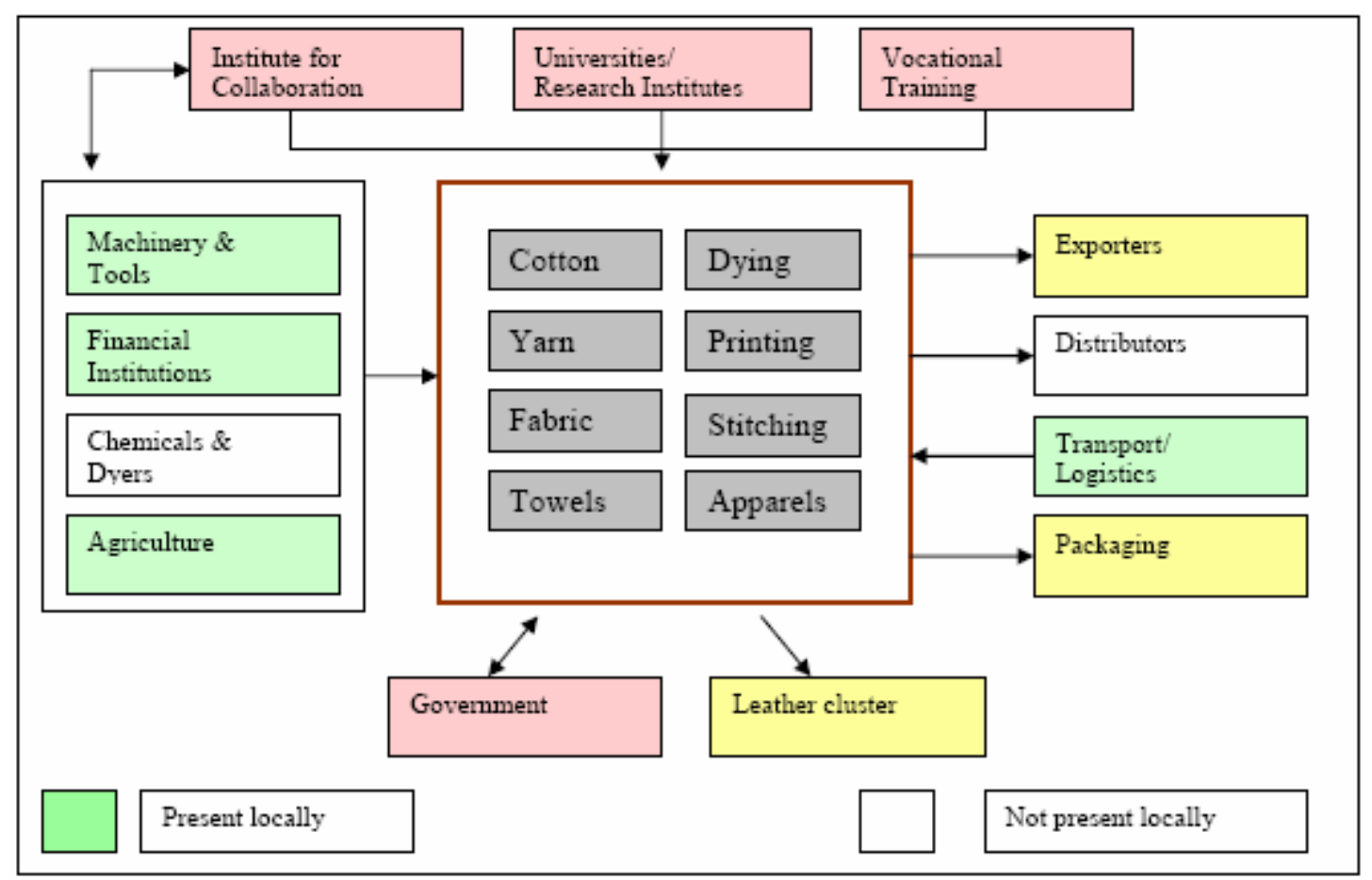

Figure 4.5. Textile Cluster Map

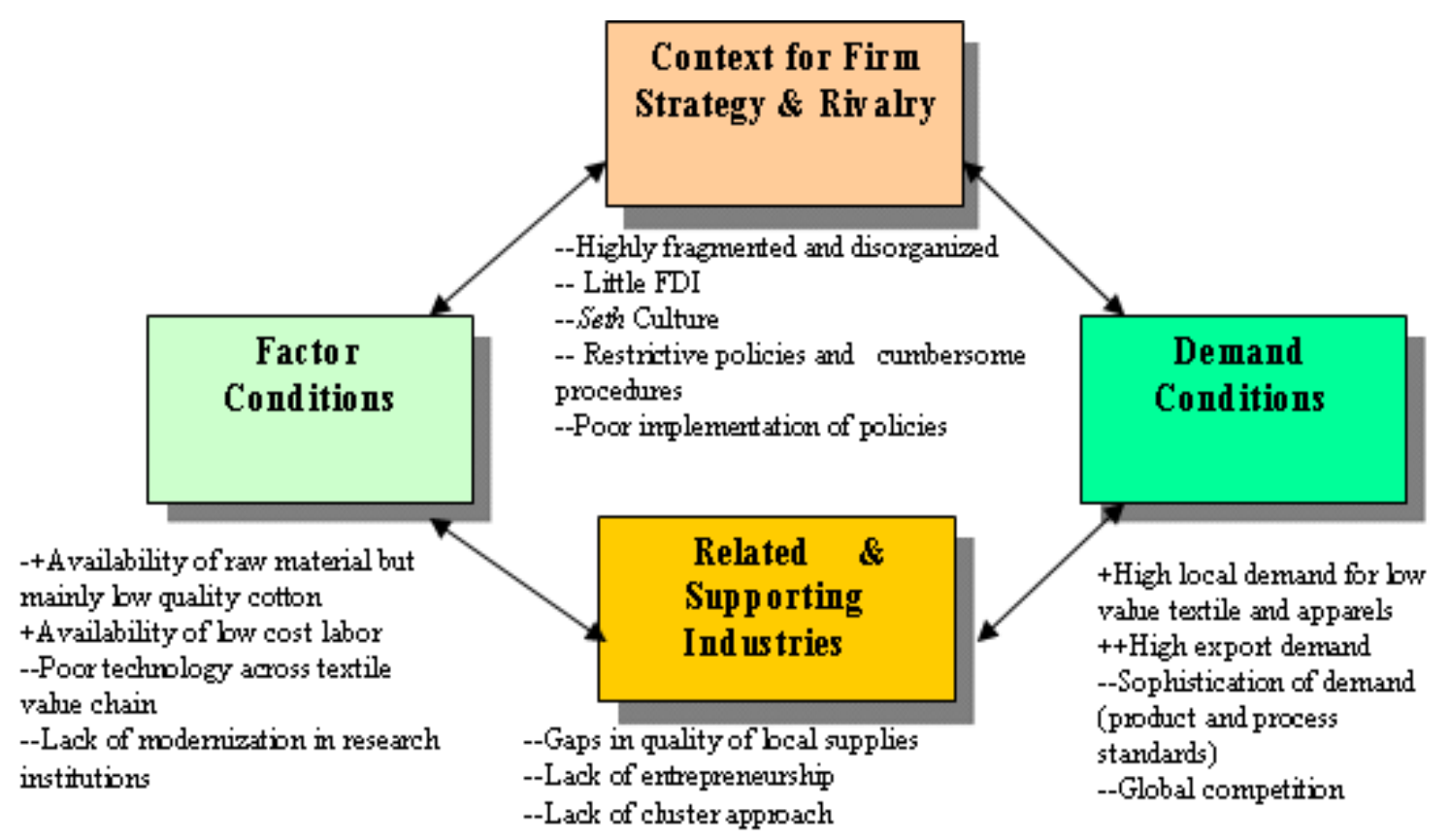

Figure 5.1. Textile Diamonds 


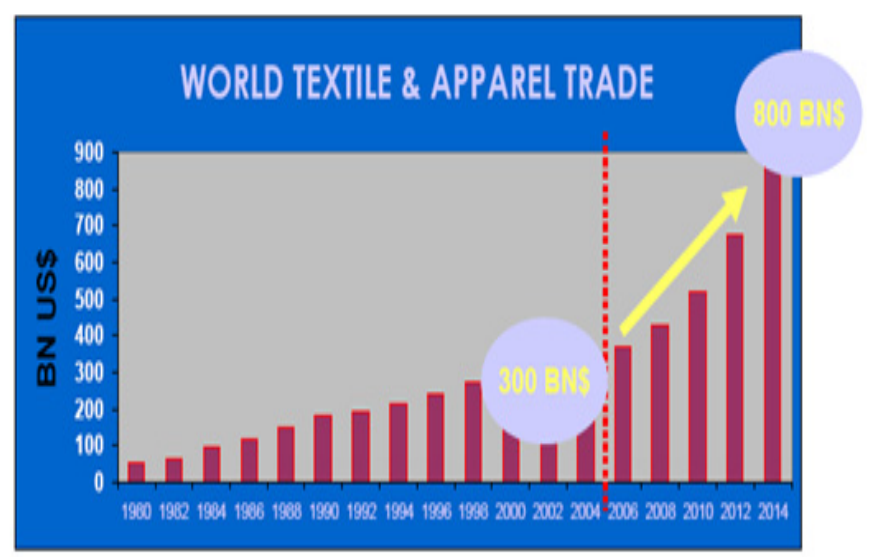

Source: Werner International USA 2005

Figure 5.2. World Export Demand

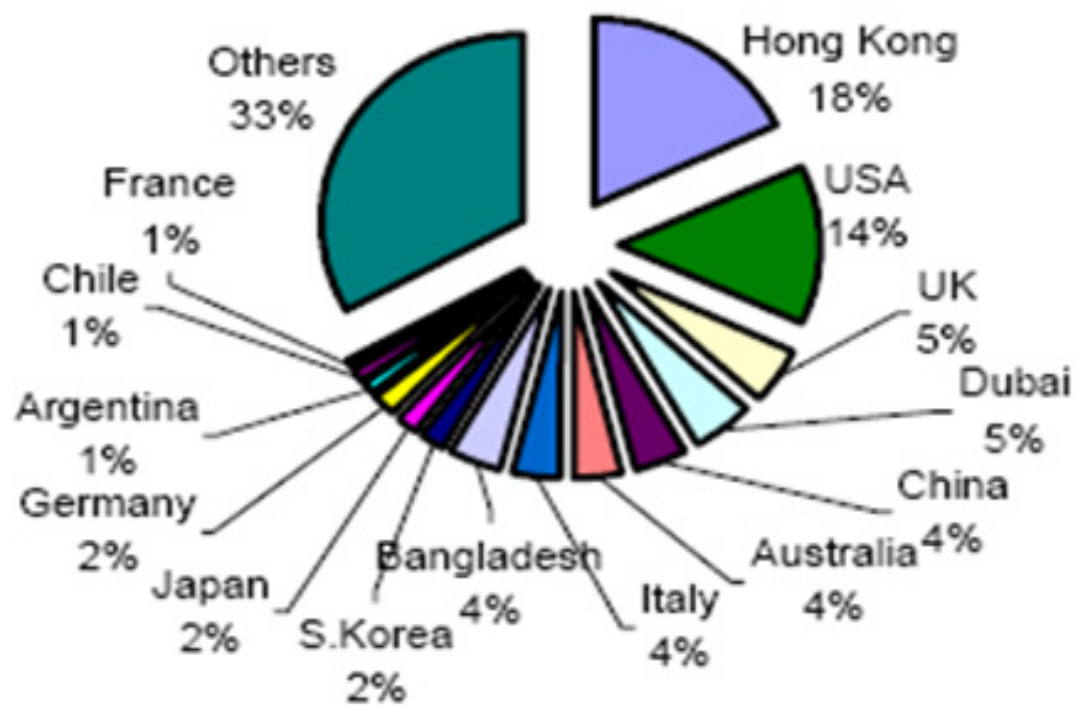

Source: SMEDA 2000

Figure 5.3. Export Destinations 


\section{Weaknesses}

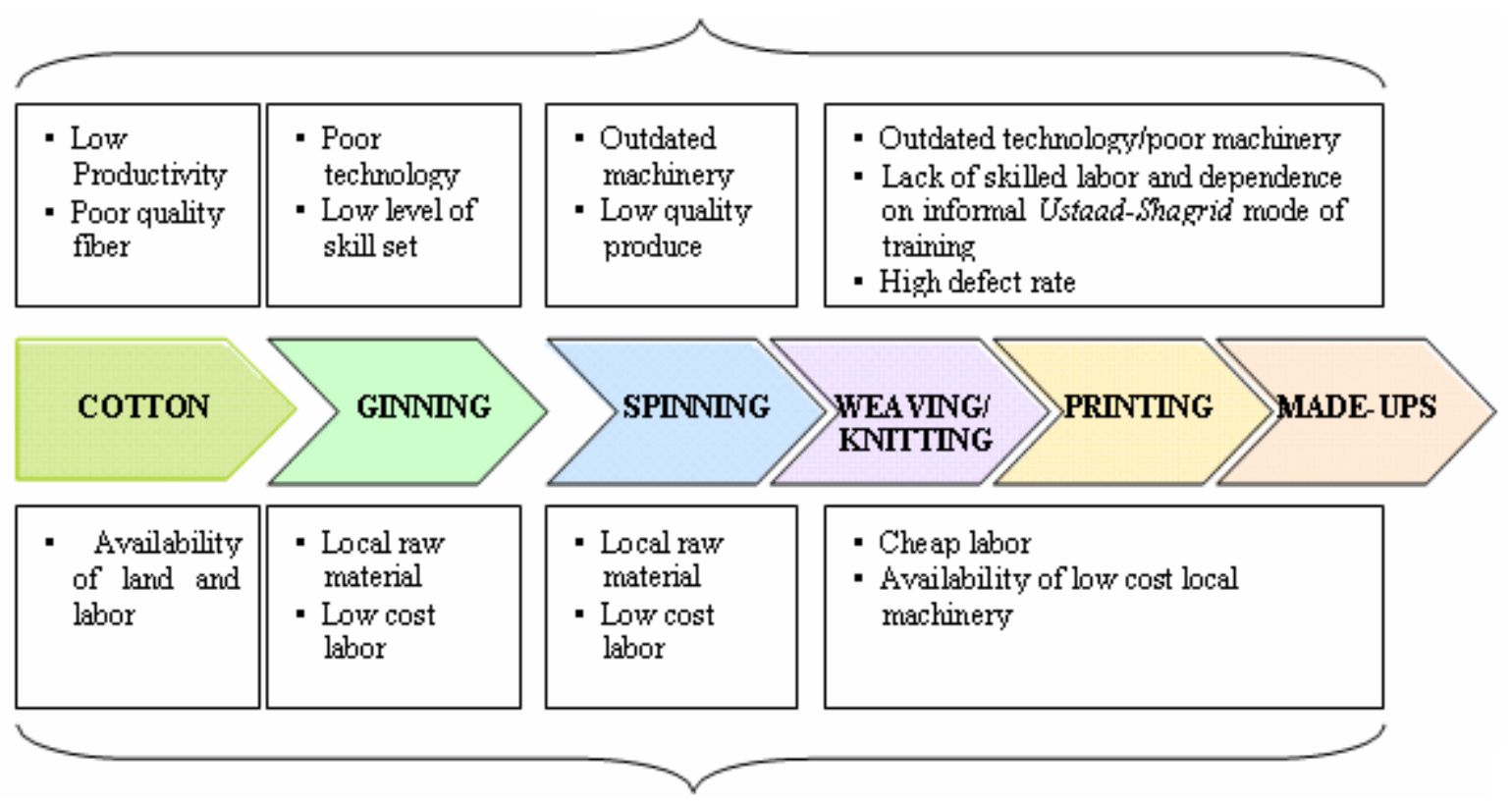

Figure 5.4. Factor Conditions across Textile \& Apparel Value Chain 